\title{
Congenital malformations and childhood neoplasms
}

\author{
IAN LECK \\ From the Department of Community Medicine, University of Manchester
}

When the current pattern of mortality in late fetal life, infancy, and childhood is compared with that of 80 or even 40 years ago, the rates for malformations and cancer stand out as having declined less than those for any of the other common causes of death. In England and Wales in 1973, 22\% of stillbirths and infant deaths were attributed to malformationsmore than to any other of the classes in which causes of perinatal death are grouped - and $16 \%$ of deaths in children between 1 and 15 years old were ascribed to neoplasms - more than to any other class of disorders with the exception of accidents. Even the moderate improvements in survival achieved by advances in the treatment of these conditions have not been all gain, since many of the survivors are left with residual handicaps or develop other disorders later.

There is some evidence that in each of these groups of conditions, as in the chromosomal anomalies, the cases that present clinically are only the tip of an iceberg, the rest of which consists of affected individuals who are eliminated as miscarriages, or (in cases with latent neoplasms) as deaths assigned to other causes. External malformations appear to be much commoner in both spontaneous and induced abortions than in fetuses that survive until late pregnancy; but many of the aborted cases of these malformations have chromosomal anomalies and, therefore, seem unlikely to have much in common aetiologically with the cases seen at birth, in which the chromosomes generally appear normal (Nishimura, 1975; Creasy and Alberman, 1976). Creasy and Alberman suggest that in the London area the prevalence of neural tube defects not associated with demonstrable chromosomal defects among embryos alive at the beginning of the eighth week of gestation may be about $0.5 \%$, but estimates of this kind for other malformations are not available.

The evidence that many individuals with neoplasia are eliminated before their condition becomes apparent is strongest for leukaemia. Chest infections occur especially often in children who later develop clinical leukaemia, and some in the preleukaemic state must succumb as a result, especially where infections are common and poorly treated (Kneale,
1971). Stewart $(1973,1975)$ has recently reported that clinical leukaemia is relatively rare in certain categories of children among whom stillbirth and cot death occur especially often, and speculates that these events too may preferentially eliminate some children with latent leukaemia; but the evidence is not conclusive, and we are no more in a position to estimate for neoplasms than for malformations how many affected individuals are eliminated before they can be identified.

\section{Malformations}

FREQUENCY AT BIRTH

Regarding the frequency of malformations in late fetal life and of clinical cancer in children, it is of course possible to be much more certain; but even some of these figures must be interpreted with caution. Among the common potentially lethal or handicapping malformations (Table 1), there are only three about which no special problems of definition ariseanencephaly, spina bifida, and cleft lip-and the first two of these vary in prevalence at birth by a factor of three between the south east and the north west of the United Kingdom. The frequency of cardiac defects is difficult to estimate because some of these defects are not diagnosed till several years after birth, some undergo spontaneous cure, and in some patients the diagnosis is uncertain. The figures for pyloric stenosis do not include patients who respond to medicial treatment at home but only those treated in hospital.

Positional foot deformities are reported at birth in very many children, but apart from the cases of nonpostural talipes equinovarus most of these deformities disappear spontaneously or after minimal treatment and can hardly be called malformations. A somewhat similar situation exists in regard to dislocation and instability of the hip. The proportion of children in whom this can be detected in the neonatal period, though it varies according to the observer, is almost always far greater than the proportion who used to develop symptomatic dislocations in the days before neonatal examination of the hips was introduced, so there can be little doubt that even in the absence of 
Table 1 Recent British estimates of prevalence at birth of potentially lethal or handicapping malformations (excluding Down's disease)

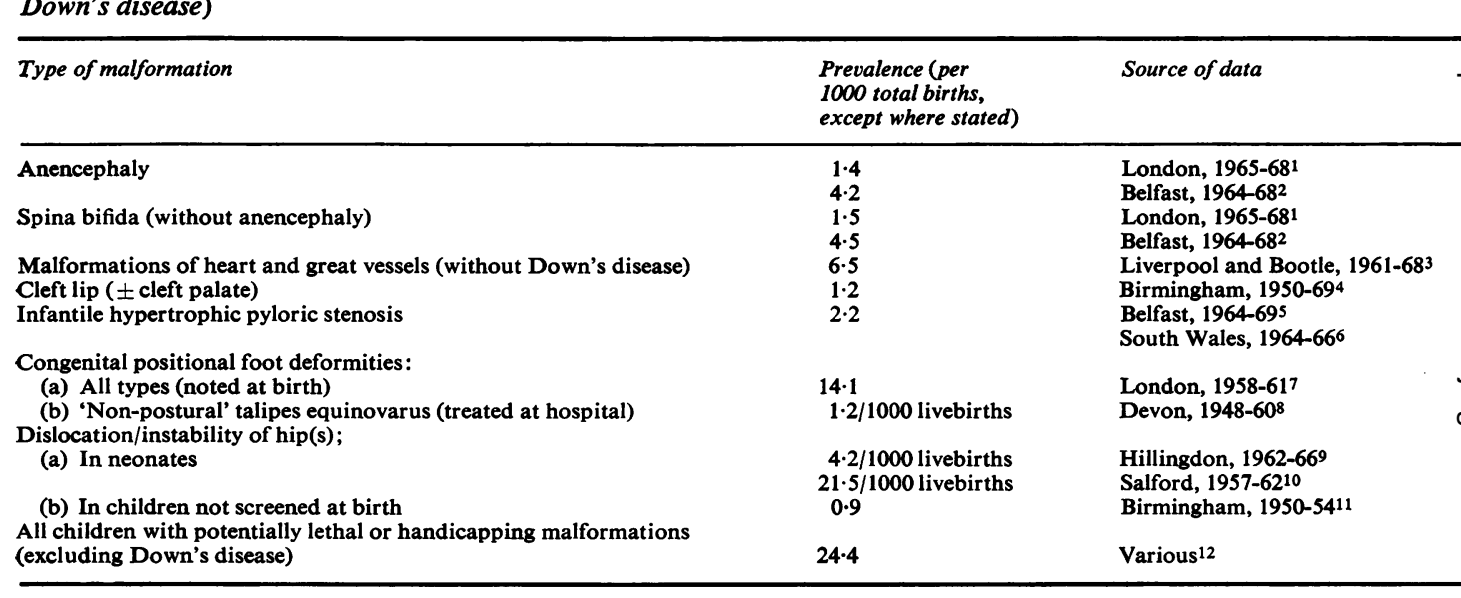

1Carter and Evans (1973); encephalocele included under spina bifida.

2Elwood and Nevin (1973); encephalocele included under anencephaly.

3Kenna et al. (1975).

4Leck (1972).

sDodge (1975).

6Richards and Lowe (1971).

7Alberman (1965).

8 Wynne-Davies (1964).

9Finlay et al. (1967); infants examined within 36 hours of birth (excluding cases with spina bifida).

10Barlow (1962); infants examined within three and a half days of birth.

11 Leck et al. (1968).

12Based on above estimates for cardiac malformations, pyloric stenosis and non-postural talipes equinovarus; on Smithells (1968) and Richarde् and Lowe (1971) for hydrocephaly; on Roberts and Lloyd (1973) for penial and perineal hypospadias; and on Leck et al. (1968) for other defects excluding conditions of minor importance such as accessory auricle, glandular hypospadias, most postural foot deformities, polydactyly an $\overline{6}$ syndactyly.

any treatment most of the hips that are unstable at birth would stabilise spontaneously.

Table 1 also includes an estimate of the proportion of all children in whom potentially lethal or handicapping malformations other than Down's disease are present. This proportion- $2.4 \%$-is based on our study of all malformations in Birmingham children born in 1950 to 1954 , but defects such as polydactyly and accessory auricle, which usually cause no appreciable handicap or threat to life, have been excluded. Also, there are a few types of defects, for example congenital heart disease, for which the results of other British studies are felt to be more reliable than the Birmingham figures, and for these the former results have been included in the total instead of the latter.

Although anencephaly and spina bifida are the only malformations that are known to vary much in incidence between different parts of the United Kingdom, most of the other common defects are several times more frequent in some countries or races than in others; most affect one sex more often than the other; and some have been noted to vary according to season and year of birth, socioeconomic status, maternal age and parity, and obstetric factors such as multiple pregnancy and breech presentation $\overrightarrow{\overrightarrow{0}}$ The well-established variations of this kind are summarised in Table 2. Many of them are not found in all populations and groups, or are more pronounced? in some than in others; for example, there is evidences that the increase in the frequency of anencephalyo during the late 1950's was virtually confined tog females, and that both the common neural tube defects occur especially often in the first born children? of young mothers in England but not in Israel.

\section{SEVERITY}

Some indication of the severity of the common malformations is given by the percentages of thoson affected who survive to various ages. Recent British estimates of the proportions of children (including stillbirths) with various malformations who are alivew at 1 week, 1 year, and in some cases 5 years after birth are given in Table 3. Most of these figures relateo to children born in South Wales in 1964 to 1966 . Aș the usual policy in treating spina bifida has changed? since then from one of aggressive intervention in allo cases to one which restricts this intervention to the less disabled cases, the survival rates to be expected? with the latter policy are given as well as those 
Table 2 Principal variations in frequency of common malformations ${ }^{1}$

\begin{tabular}{|c|c|c|c|}
\hline Type of malformation & High risk sex & Places/races of highest risk & Other high risk factors \\
\hline Anencephaly, spina bifida & Female & Ireland & $\begin{array}{l}\text { Births in certain years (e.g. late } \\
1950 \text { 's in England) and in winter; } \\
\text { extremes of maternal age and } \\
\text { parity } \\
\text { Low socioeconomic status }\end{array}$ \\
\hline $\begin{array}{l}\text { Malformations of heart and great } \\
\text { vessels }\end{array}$ & $\begin{array}{l}\text { Female for persistent ductus } \\
\text { arteriosus; male for transposi- } \\
\text { tion, coarctation, aortic stenosis }\end{array}$ & $\begin{array}{l}\text { High altitudes for patent } \\
\text { ductus arteriosus }\end{array}$ & $\begin{array}{l}\text { High maternal age } \\
\text { Monozygotic twinning }\end{array}$ \\
\hline Cleft lip ( \pm cleft palate) & Male & Mongoloid peoples & High maternal age \\
\hline Infantile hypertrophic pyloric stenosis & Male & Northern Europe & Primogeniture \\
\hline Talipes equinovarus & Male & Polynesian peoples & - \\
\hline Dislocation of hip(s) & Female & American Indians; Lapps & $\begin{array}{l}\text { Winter births; primogeniture } \\
\text { Breech presentation }\end{array}$ \\
\hline
\end{tabular}

${ }^{1}$ From reviews by Leck $(1974,1976)$.

Table 3 Survival of children (including stillbirths) with malformations

\begin{tabular}{|c|c|c|c|}
\hline \multirow[t]{2}{*}{ Type of malformation } & \multicolumn{3}{|c|}{ Percentage alive } \\
\hline & $\begin{array}{l}\text { One week } \\
\text { after birth }\end{array}$ & $\begin{array}{l}\text { One year } \\
\text { after birth }\end{array}$ & $\begin{array}{l}\text { Five years } \\
\text { after birth }\end{array}$ \\
\hline $\begin{array}{l}\text { Anencephaly } 1 \\
\text { Spina bifida }\end{array}$ & 0 & 0 & 0 \\
\hline with routine intervention ${ }^{2}$ & 62 & 41 & 33 \\
\hline $\begin{array}{l}\text { with selective intervention }{ }^{3} \\
\text { Malformation of heart and } \\
\text { great vessels (without }\end{array}$ & 62 & 25 & - \\
\hline Down's disease) ${ }^{4}$ & 82 & 60 & 57 \\
\hline Cleft lip and/or palate 1 & 90 & 89 & - \\
\hline $\begin{array}{l}\text { Infantile hypertrophic } \\
\text { pyloric stenosis } 1 \\
\text { Congenital positional foot } \\
\text { deformities (without }\end{array}$ & 100 & 98 & - \\
\hline $\begin{array}{l}\text { spina bifida) }^{1} \\
\text { All children with potentially } \\
\text { lethal or handicapping } \\
\text { malformations (excluding }\end{array}$ & 97 & 95 & - \\
\hline Down's disease) ${ }^{4}$ & 78 & 69 & 67 \\
\hline
\end{tabular}

1 From Richards (1973).

2From Richards (1973) and Laurence (1974).

3 From Knox (1967) and Lorber (1973).

${ }^{4}$ From mortality statistics for England and Wales in 1973 (RegistrarGeneral, 1975), adjusted to allow for deaths of malformed children not attributed to malformations and assuming that prevalence at birth was as in Table 1.

observed with the former. As the ascertainment of cardiac malformations was probably incomplete in the South Wales series and the survival of all the children with serious malformations in this series was not documented, survival of children in these groups has been estimated from the numbers of deaths ascribed to these causes in the Registrar General's Annual Review. To make these estimates it was assumed that the prevalence at birth of those affected was the same as that in Table 1, and that among the deaths that occurred in these children, the proportions not ascribed to malformations were the same as we estimated them to have been in Birmingham a few years earlier. The results suggest that about $\frac{4}{7}$ of the children with cardiac malformations and $\frac{2}{3}$ of all the malformed survive to 5 years.

\section{TRANSMISSIBILITY}

The transmissibility of the common malformations is examined in Table 4, using mainly figures on frequency in sibs and offspring of index patients which Professor Carter has published recently. It will be seen that the percentages of first degree relatives affected-in each case by the same malformations as the index patients-all lie between $2 \%$ and $5 \%$, except that in pyloric stenosis and hip dislocation-which are very much commoner in one sex than the otherthe recurrence risks seem to be rather higher when the index patient is of the less often affected sex. These findings are consistent with the hypothesis that the aetiology of each of the common defects involves a multiplicity of factors, some genetic and others environmental. The rates are all much lower than one would expect them to be if single genes of major effect were involved, and suggest that the part played by new mutations in maintaining these conditions is small.

Table 4 Recurrence risks of common malformations ${ }^{1}$

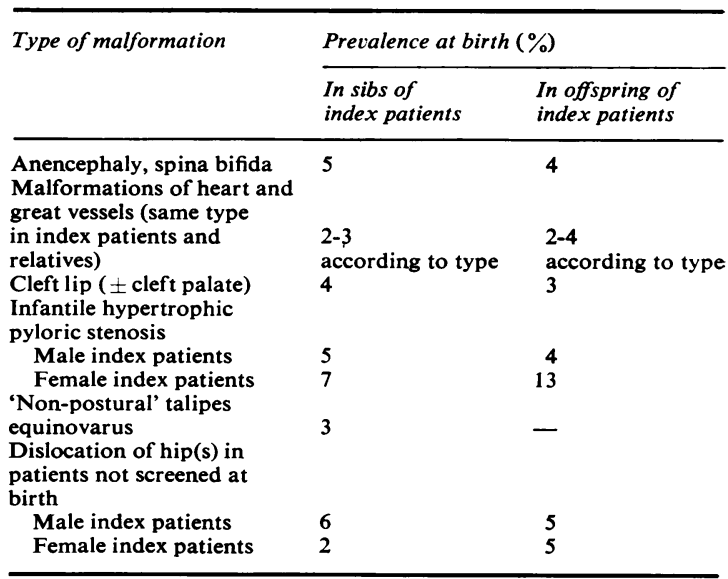

${ }^{1}$ From Wynne-Davies (1964) for talipes, and Carter (1976) for other malformations. 


\section{Childhood neoplasms}

\section{FREQUENCY}

Our knowledge about frequency and transmissibility of childhood neoplasms is less extensive. The only completely satisfactory way to classify these is on the basis of histogenesis, preferably assessed by an expert in children's tumour pathology. The most extensive population-based series to have been studied in this way is probably that of the University of Manchester Children's Tumour Registry, which covers cases presenting in 1954 to 1973 in children under 15 who lived in the old Manchester Regional Hospital Board area, which had a child population of about one million. The annual incidence of malignant neoplasms in this population (Table 5), is about 90 per million. When allowance is made for infant and child deaths, the average time for which a child under 15 is at risk is about 14.7 years, and by multiplying the annual incidence by this figure it can be estimated that 1.36 per 1000 children born alive present with a malignant neoplasm before they are 15 years old.

The data from the Manchester Registry are compared with what are probably the most reliable data available for other parts of the world in Table 6 . The greatest absolute differences are between the rates for leukaemia in 'White' and 'Black' Americans, and between those for glioma in America and Japan, though there is doubt about some of the Japanese rates because it is not clear from the report from which they are taken whether benign neoplasms have been included, nor whether such non-gliomatous intracranial tumours as were included have been grouped with the gliomata or classed as miscellaneous. A more detailed classification would certainly reveal further differences, since it is known that in Japan for example pinealoma is much more common and a much higher

Table 5 Frequency of malignant neoplasms in children under 15 years old (Manchester Regional Hospital Board area, $1954-73)^{1}$

\begin{tabular}{lcl}
\hline Type of neoplasm & $\begin{array}{l}\text { Annual } \\
\text { incidence } \\
\text { (per million) }\end{array}$ & $\begin{array}{l}\text { Cumulative incidence } \\
\text { (per thousand } \\
\text { liveborn children })\end{array}$ \\
\hline Wilms' tumour & $5 \cdot 5$ & 0.08 \\
Glioma & 19.3 & $0 \cdot 28$ \\
$\begin{array}{l}\text { Neuroblastoma, } \\
\text { ganglioneuroblastoma }\end{array}$ & 6.6 & $0 \cdot 10$ \\
$\begin{array}{l}\text { Retinoblastoma } \\
\text { Leukaemia }\end{array}$ & $3 \cdot 2$ & $0 \cdot 05$ \\
Other lymphoid and & 32.2 & $0 \cdot 47$ \\
haematopoietic & & \\
neoplasms & $7 \cdot 2$ & $0 \cdot 11$ \\
Miscellaneous & $18 \cdot 2$ & $0 \cdot 27$ \\
\hline Total & 92.2 & $1 \cdot 36$ \\
\hline
\end{tabular}

1J. M. Birch, I. Leck, H. B. Marsden, P. H. Morris Jones, and J. K. :Steward, in preparation.
Table 6 Annual incidence of malignant neoplasms in children of different countries

\begin{tabular}{|c|c|c|c|c|}
\hline \multirow[t]{3}{*}{ Type of neoplasm } & \multicolumn{4}{|c|}{$\begin{array}{l}\text { Annual incidence per million children } \\
\text { under } 15\end{array}$} \\
\hline & \multirow{2}{*}{$\begin{array}{l}\text { Manchester } \\
\text { RHB area } \\
1954-73\end{array}$} & \multicolumn{2}{|c|}{ US.A, 1969-711 } & \multirow{2}{*}{$\begin{array}{l}\text { Japan } \\
1972^{2}\end{array}$} \\
\hline & & 'Whites' & 'Blacks' & \\
\hline Wilms' tumour & 5 & 8 & 8 & 5 \\
\hline Glioma & 19 & 23 & 23 & $9-14$ \\
\hline $\begin{array}{l}\text { Neuroblastoma, } \\
\text { ganglioneuroblastoma }\end{array}$ & 7 & 9 & 7 & 7 \\
\hline Retinoblastoma & 3 & 3 & 3 & 5 \\
\hline Leukaemia & 32 & 42 & 24 & 42 \\
\hline \multirow{3}{*}{$\begin{array}{l}\text { Other lymphoid and } \\
\text { haematopoietic } \\
\text { neoplasms } \\
\text { Miscellaneous }\end{array}$} & & & & \\
\hline & & 13 & 14 & 7 \\
\hline & 18 & 26 & 19 & $13-17$ \\
\hline Total & 91 & 124 & 98 & $88-97$ \\
\hline
\end{tabular}

1 Young and Miller (1975).

2National Survey of Chronic Diseases, cited by Hanawa (1975).

proportion of childhood leukaemias are classed as $\underset{\mathbb{\Phi}}{\mathscr{D}}$ myeloid than in the West.

\section{SEVERITY}

Survival statistics computed by actuarial methods for the Manchester cases that presented in 1969 to 1973 are given in Table 7. Earlier cases were not

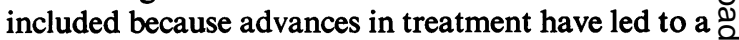
considerable decline in the mortality from some child- $\triangle$ hood cancers, notably leukaemia, in recent years-a $\vec{\Rightarrow}$ decline which even the 1969 to 1973 figures do not $\frac{9}{3}$ completely reflect. According to these figures, more than $\frac{3}{5}$ of those who presented lived for at least 1 year, and nearly $\frac{2}{5}$ are surviving for at least 5 years.

Table 7 Survival of children who presented with malignant neoplasms in 1969-73 (Manchester Regional Hospital Board area) ${ }^{1}$

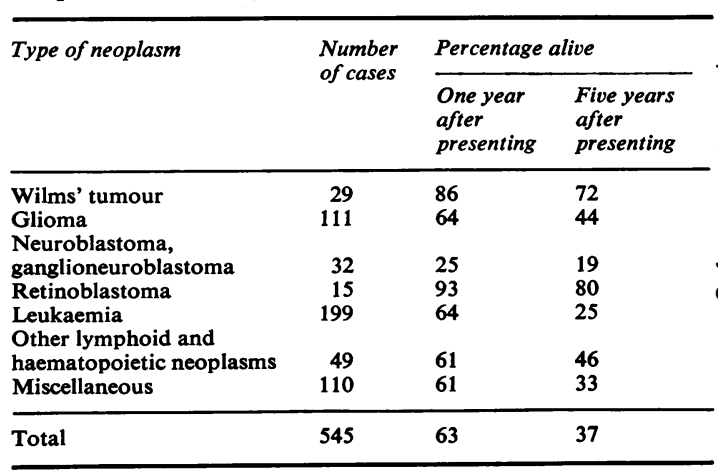

1See footnote to Table 5 . 
Table 8 Recurrence risks of childhood neoplasms that were malignant and/or arose in central nervous system, excluding retinoblastoma (Great Britain, 1953-72 ${ }^{1}$; USA, 1960-672)

\begin{tabular}{|c|c|c|c|}
\hline \multirow[t]{2}{*}{ Types of neoplasms } & \multicolumn{2}{|c|}{$\begin{array}{l}\text { Number of ascertain- } \\
\text { ments of sib pairs }\end{array}$} & \multirow[t]{2}{*}{$\begin{array}{l}\text { Relative } \\
\text { risk }\end{array}$} \\
\hline & Observed & Expected & \\
\hline \multicolumn{4}{|c|}{ Sibs with neoplasms of same group: } \\
\hline Wilms' tumour & 4 & 0.4 & $10 \cdot 0$ \\
\hline CNS neoplasm & 24 & $3 \cdot 7$ & 6.5 \\
\hline Neuroblastoma, & 3 & 0.6 & $5 \cdot 0$ \\
\hline Leukaemia & 35 & $15 \cdot 6$ & $2 \cdot 2$ \\
\hline Other lymphoid and & & & \\
\hline haematopoietic neoplasms & 5 & 0.8 & $6 \cdot 3$ \\
\hline Miscellaneous & 12 & 1.9 & $6 \cdot 3$ \\
\hline \multicolumn{4}{|l|}{ Sibs with neoplasms of different } \\
\hline $\begin{array}{l}\text { One CNS neoplasm, one } \\
\text { miscellaneous }\end{array}$ & 31 & $6 \cdot 1$ & $5 \cdot 1$ \\
\hline $\begin{array}{l}\text { One neuroblastoma, one } \\
\text { miscellaneous }\end{array}$ & 7 & $2 \cdot 4$ & 2.9 \\
\hline Other combinations & 72 & $60 \cdot 3$ & $1 \cdot 2$ \\
\hline Total & 193 & $91 \cdot 8$ & $2 \cdot 1$ \\
\hline
\end{tabular}

1Draper et al. (1977).

2Miller (1971).

\section{TRANSMISSIBILITY}

Partly because the survival rates for children who presented in earlier years were less good, the numbers of offspring of these children that have been studied are too small to indicate how often transmission from parent to child occurs, though the limited data that are available suggest that it is rare-except of course in retinoblastoma, where nearly half of all cases are believed to be the result of an autosomal dominant gene. Data on the frequency of recurrence of other cancers in sibs from two large series are shown in Table 8, which suggests that none of the common cancers recurs more than 10 times as often in sibs as in the general population. The increases thus tend to be even smaller than those exhibited by the more common malformations, which suggests that the role of the genotype in aetiology may also be smaller.

The production of the data for the Manchester Regional Hospital Board area shown in Tables 5 to 7 was supported by United States Public Health Service Research Grant No. CA14992 from the National Cancer Institute.

\section{References}

Alberman, E. D. (1965). The causes of congenital club foot. Archives of Disease in Childhood, 40, 548-554.

Barlow, T. G. (1962). Early diagnosis and treatment of congenital dislocation of the hip. Journal of Bone and Joint Surgery, 44B, 292-301.
Carter, C. O. (1976). Genetics of common single malformations. British Medical Bulletin, 32, 21-26.

Carter, C. O., and Evans, K. (1973). Spina bifida and anencephalus in Greater London. Journal of Medical Genetics, 10, 209-234.

Creasy, M. R., and Alberman, E. D. (1976). Congenital malformations of the central nervous system in spontaneous abortions. Journal of Medical Genetics, 13, 9-16.

Dodge, J. A. (1975). Infantile hypertrophic pyloric stenosis in Belfast. Archives of Disease in Childhood, 50, 171-178.

Draper, G. J., Heaf, M. M., and Kinnear Wilson, L. M. (1977). Occurrence of childhood cancers among sibs and estimation of familial risks. Journal of Medical Genetics, 14, 81-90.

Elwood, J. H., and Nevin, N. C. (1973). Factors associated with anencephalus and spina bifida in Belfast. British Journal of Preventive and Social Medicine, 27, 73-80.

Finlay, H. V. L., Maudsley, R. H., and Busfield, P. I. (1967). Dislocatable hip and dislocated hip in the new-born infant. British Medical Journal, 4, 377-381.

Hanawa, Y. (1975). In All Japan Children's Cancer Registration 1969-73, pp. 31-72. Children's Cancer Association of Japan, Tokyo.

Kenna, A. P., Smithells, R. W., and Fielding, D. W. (1975). Congenital heart disease in Liverpool. Quarterly Journal of Medicine, 44, 17-44.

Kneale, G. W. (1971). Excess sensitivity of pre-leukaemics to pneumonia. A model situation for studying the interaction. of infectious disease with cancer. British Journal of Preventive and Social Medicine, 25, 152-159.

Knox, E. G. (1967). Spina bifida in Birmingham. Developmental Medicine and Child Neurology, Suppl. 13, 14-22.

Laurence, K. M. (1974). Effect of early surgery for spina bifida cystica on survival and quality of life. Lancet, 1, 301-304.

Leck, I. (1972). The etiology of human malformations: insights from epidemiology. Teratology, 5, 303-314.

Leck, I. (1974). Causation of neural tube defects. British Medical Bulletin, 30, 158-163.

Leck, I. (1976). Descriptive epidemiology of common malformations (excluding central nervous system defects). British Medical Bulletin, 32, 45-52.

Leck, I., Record, R. G., McKeown, T., and Edwards, J. H. (1968). The incidence of malformations in Birmingham, England, 1950-1959. Teratology, 1, 263-280.

Lorber, J. (1973). Early results of selective treatment of spina bifida systica. British Medical Journal, 4, 201-204.

Muller, R. W. (1971). Deaths from childhood leukaemia and solid tumors among twins and other sibs in the United States, 1960-1967. Journal of the National Cancer Institute, 46, 203-209.

Nishimura, H. (1975). Prenatal versus postnatal malformations based on the Japanese experience on induced abortions in the human being. In Aging Gametes: Their Biology and Pathology (Proceedings of the International Symposium on Aging Gametes, Seattle, Washington, 13-16 June, 1973), pp. 349-368. Ed. by R. J. Blandau. Karger, Basel.

Registrar-General (1975). Statistical Review of England and Wales for the year 1973: Part I (A): Tables, Medical.

Richards, I. D. G. (1973). Fetal and infant mortality associated with congenital malformations. British Journal of Preventive and Social Medicine, 27, 85-90.

Richards, I. D. G., and Lowe, C. R. (1971). Incidence of congenital defects in S. Wales. British Journal of Preventive and Social Medicine, 25, 59-64.

Roberts, C. J., and Lloyd, S. (1973). Observations on the epidemiology of simple hypospadias. British Medical Journal, 1, 768-770.

Smithells, R. W. (1968). Incidence of congenital abnormalities in Liverpool. British Journal of Preventive and Social Medicine, 22, 36-37. 
Stewart, A. M. (1973). Cancer as a cause of abortions and stillbirths: the effect of these early deaths on the recognition of radiogenic leukaemias. British Journal of Cancer, 27, 465 472.

Stewart, A. [M.] (1975). Infant leukaemias and cot deaths. British Medical Journal, 2, 605-607.

Wynne-Davies, R. (1964). Family studies and the cause of congenital club foot. Talipes equinovarus, talipes calcaneovalgus and metatarsus varus. Journal of Bone and Joint Surgery, 46B, 445-463.
Young, J. L., Jr., and Miller, R. W. (1975). Incidence $\stackrel{\mathrm{Q}}{f}_{\mathrm{f}}$ malignant tumours in US Children. Journal of Pediatrics, 86, 254-258.

Requests for reprints to Dr Ian Leck, Regiona Cancer Epidemiology Unit, Christie Hospital arif Holt Radium Institute, Withington, Manchest M20 9BX. 